\title{
Cloud chemistry at the Puy de Dôme: variability and relationships with environmental factors
}

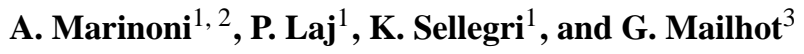 \\ ${ }^{1}$ Laboratoire de Météorologie Physique, Université Blaise Pascal, OPGC/CNRS, Clermont-Ferrand, France \\ ${ }^{2}$ Dipartimento di Scienze dell' Ambiente e del Territorio, Università degli Studi di Milano Bicocca, Italy \\ ${ }^{3}$ Laboratoire de Photochimie Moléculaire et Macromoléculaire, Université Blaise Pascal, UMR CNRS 6505, \\ Clermont-Ferrand, France
}

Received: 18 November 2003 - Published in Atmos. Chem. Phys. Discuss.: 5 February 2004

Revised: 27 April 2004 - Accepted: 6 May 2004 - Published: 12 May 2004

\begin{abstract}
The chemical composition of cloud water was investigated during the winter-spring months of 2001 and 2002 at the Puy de Dôme station (1465 m above sea level, $45^{\circ} 46^{\prime} 22^{\prime \prime} \mathrm{N}, 2^{\circ} 57^{\prime} 43^{\prime \prime} \mathrm{E}$ ) in an effort to characterize clouds in the continental free troposphere. Cloud droplets were sampled with single-stage cloud collectors (cut-off diameter approximately $7 \mu \mathrm{m}$ ) and analyzed for inorganic and organic ions, as well as total dissolved organic carbon. Results show a very large variability in chemical composition and total solute concentration of cloud droplets, ranging from a few $\mathrm{mg} \mathrm{l}^{-1}$ to more than $150 \mathrm{mg} \mathrm{l}^{-1}$. Samplings can be classified in three different categories with respect to their total ionic content and relative chemical composition: background continental (BG, total solute content lower than $18 \mathrm{mgl}^{-1}$ ), anthropogenic continental (ANT, total solute content from 18 to $50 \mathrm{mg} \mathrm{l}^{-1}$ ), and special events ( $\mathrm{SpE}$, total solute content higher than $50 \mathrm{mg}^{-1}$ ). The relative chemical composition shows an increase in anthropogenic-derived species $\left(\mathrm{NO}_{3}^{-}\right.$, $\mathrm{SO}_{4}^{2-}$ and $\mathrm{NH}_{4}^{+}$) from $\mathrm{BG}$ to $\mathrm{SpE}$, and a decrease in dissolved organic compounds (ionic and non-ionic) that are associated with the anthropogenic character of air masses.

We observed a high contribution of solute in cloud water derived from the dissolution of gas phase species in all cloud events. This was evident from large solute fractions of nitrate, ammonium and mono-carboxylic acids in cloud water, relative to their abundance in the aerosol phase. The comparison between droplet and aerosol composition clearly shows the limited ability of organic aerosols to act as cloud condensation nuclei. The strong contribution of gas-phase species limits the establishment of direct relationships between cloud water solute concentration and LWC that are expected from nucleation scavenging.
\end{abstract}

Correspondence to: A. Marinoni

(angela.marinoni@unimib.it)

\section{Introduction}

The fundamental role of cloud droplets as media for chemical reactions has long been recognized (Jacob et al., 1986; Chameides and Davis, 1983; Calvert et al., 1986; Liang and Jacobson, 1999; Laj et al., 1997a; Möller et al., 1996; Collett et al., 1999). Chemical and physical processes in multiphase systems significantly influence the transport, vertical redistribution, chemical transformation, and removal of chemical species from the atmosphere, and hence impact on the lifetime of both aerosols and gases. As many of the existing chemical species formed in the gas phase can dissolve and react efficiently in the liquid phase, aqueous-phase reactions potentially act either as a sink or source for atmospheric trace compounds, depending on the physical and chemical characteristics of cloud droplets (Warneck, 1986). In addition, due to their high concentration of solutes, fogs and clouds play a crucial role in the deposition of pollutants. Clouds and fogs can significantly affect terrestrial and aquatic ecosystems, acting on a regional scale as a primary source of nutrients to ecosystems and as a potential source of toxic chemicals (Glotfelty et al., 1987).

The chemical composition of cloud droplets is determined by chemical and physical processes that include (i) the dynamics of cloud formation, (ii) the composition and concentration of aerosols that are dissolved in the droplets from both nucleation and impaction scavenging, (iii) the transfer of volatile species across the air/water interface during the lifetime of the cloud, and (iv) the chemical reactions that can take place in the liquid phase. Since each of these processes can modify the original solute concentration of cloud droplets, the chemical composition of cloud droplets results from a combination of all three major processes.

Assessing the importance of multiphase chemical processes in the global atmospheric chemical cycle is rather complicated, given the variety of condensed matter and gaseous species that can participate in such reactions. For 
Table 1. Description of sampling conditions at PDD during winter/spring 2001 and 2002 for the cloud events used in the present study. Corresponding aerosol sampling is indicated when available as well as air mass origin derived by HYSPLIT transport and dispersion model.

\begin{tabular}{|c|c|c|c|c|c|c|c|c|}
\hline \multirow{2}{*}{$\begin{array}{l}\text { Cloud } \\
\text { Event }\end{array}$} & \multicolumn{3}{|c|}{$\begin{array}{c}\text { CLOUD } \\
\text { SAMPLING }\end{array}$} & \multicolumn{3}{|c|}{$\begin{array}{l}\text { AEROSOL } \\
\text { SAMPLING }\end{array}$} & \multirow{2}{*}{$\begin{array}{l}\text { AIR MASS } \\
\text { ORIGIN }\end{array}$} & \multirow{2}{*}{$\begin{array}{l}\text { AIR MASS } \\
\text { CLASS }\end{array}$} \\
\hline & Start & End & $\begin{array}{l}\mathbf{N}^{\circ} \text { Samples } \\
\text { (supercooled } \\
\text { samples) }\end{array}$ & $\begin{array}{l}\text { Samples } \\
\text { during } \\
\text { the day }\end{array}$ & Start & End & & \\
\hline 1 & 08/02/01 & 09/02/01 & $6(1)$ & $83 \%$ & & & $\mathrm{~W} / \mathrm{N}$ (marine) & BG \\
\hline 2 & $12 / 02 / 01$ & $14 / 02 / 01$ & $9(6)$ & $56 \%$ & $12 / 02 / 01$ & $14 / 02 / 01$ & E (continental) & ANT \\
\hline 3 & $17 / 02 / 01$ & $18 / 02 / 01$ & $11(11)$ & $45 \%$ & $17 / 02 / 01$ & $18 / 02 / 01$ & E (continental) & ANT \\
\hline $4 \mathrm{a}$ & $22 / 02 / 01$ & 23/02/01 & $10(7)$ & $33 \%$ & $22 / 02 / 01$ & $23 / 02 / 01$ & $\mathrm{~W} / \mathrm{N}$ (marine) & BG \\
\hline $4 b$ & 23/02/01 & 24/02/01 & $7(7)$ & $55 \%$ & $23 / 02 / 01$ & $24 / 02 / 01$ & W/N (marine) & BG \\
\hline 5 & 28/02/01 & 01/03/01 & $13(13)$ & $62 \%$ & $28 / 02 / 01$ & 01/03/01 & $\mathrm{W}$ (marine) & BG \\
\hline 6 & 02/03/01 & 03/03/01 & $8(1)$ & $43 \%$ & $14 / 02 / 02$ & $22 / 02 / 02$ & W/SW (marine) & BG \\
\hline 7 & 08/03/01 & 08/03/01 & $2(0)$ & $100 \%$ & $22 / 02 / 02$ & 01/03/02 & $\mathrm{W}$ (marine) & BG \\
\hline 8 & 05/04/01 & 06/04/01 & $1(0)$ & $0 \%$ & $01 / 03 / 02$ & $7 / 03 / 02$ & $\mathrm{E}($ continental $)$ & ANT \\
\hline 9 & $14 / 02 / 02$ & $15 / 02 / 002$ & $1(1)$ & $100 \%$ & 07/03/02 & $14 / 03 / 02$ & W/N(marine/continental) & ANT \\
\hline 10 & $22 / 02 / 02$ & $22 / 02 / 02$ & $1(0)$ & $100 \%$ & $14 / 03 / 02$ & $22 / 03 / 02$ & $\mathrm{~W}$ (marine) & BG \\
\hline 11 & $27 / 02 / 02$ & $27 / 02 / 02$ & $1(1)$ & $100 \%$ & $04 / 04 / 02$ & $11 / 04 / 02$ & $\mathrm{~W}$ (marine) & ANT \\
\hline 12 & 28/02/02 & 28/02/02 & $1(0)$ & $100 \%$ & $11 / 04 / 02$ & $19 / 04 / 02$ & N/W(continental/marine) & BG \\
\hline 13 & 07/03/02 & 07/03/02 & $1(0)$ & $100 \%$ & $19 / 04 / 02$ & $25 / 04 / 02$ & $\mathrm{~N}$ (Paris) & ANT \\
\hline 14 & $13 / 04 / 02$ & $14 / 04 / 02$ & $3(0)$ & $40 \%$ & $25 / 04 / 02$ & 02/05/02 & $\mathrm{N}$ (Paris) & $\mathrm{SpE}$ \\
\hline 15 & 03/05/02 & 05/05/02 & $1(0)$ & $28 \%$ & $02 / 05 / 02$ & 09/05/02 & $\mathrm{W}$ (marine) & ANT \\
\hline 16 & $11 / 05 / 02$ & $12 / 05 / 02$ & $1(0)$ & $0 \%$ & $09 / 05 / 02$ & $16 / 05 / 02$ & W/N (marine) & BG \\
\hline
\end{tabular}

example, liquid phase mechanisms linked to the process of acidification of precipitation are well understood, especially for sulphur and nitrogen compounds (Warneck, 1986; Jaeschke, 1986; Lelieveld and Crutzen, 1991). On the contrary, it is only recently that attention has focused on the central role of clouds in the alteration of the oxidizing capacity of the atmosphere, through reactions involving both free radicals (Lelieveld and Crutzen, 1991; Lawrence and Crutzen, 1998) and/or organic species (Aneja, 1993; Khwaja et al., 1995; Fuzzi and Zappoli, 1996; Krivacsy et al., 2000; Hitzenberger et al., 2000).

The inorganic fraction of cloud composition has been studied extensively (Chandler et al., 1988a, b; Collett et al., 1993, 1995; Erel et al., 1993; Fuzzi et al., 1992, 1998; Hegg and Hobbs, 1986). While data on the organic content are sparse, it is clear that organic content can constitute a significant fraction of the solute mass (Aneja, 1993; Fuzzi and Zappoli, 1996; Novakov and Penner, 1993; Hadi et al., 1995). The nature of the organic compounds present in cloud droplets is highly variable, and the number of chemical species that have been identified at present is extremely high (Herckes et al., 2002; Decesari et al., 2001; Cappiello et al., 2003).

Given the dispersed nature of aerosol particles, gases, and the environmental conditions leading to the formation of clouds, the chemistry of liquid atmospheric phase is highly variable. The Liquid Water Content (LWC) is one of the major factors that control the concentration in the liquid phase
(Junge, 1963; Elbert et al., 2000; Möller et al., 1996). As expected, concentrations of dissolved species often display an inverse relationship with LWC (Pilié et al., 1975; Munger et al., 1983; Jacob, 1984; Führer, 1986; Fuzzi, 1986; Gervat et al., 1984; Aneja et al., 1990), but other parameters can locally complicate the relationship between droplet concentrations and cloud microphysics. For example, the initial chemical composition of cloud water appears to be driven largely by the composition of the aerosol particles that serve as Cloud Condensation Nuclei (CCN). Finally, the contribution of ambient soluble gases can significantly change the chemical composition of droplets (Jacob et al., 1986, 1987). These factors are not adequately treated in present-day atmospheric models, where solute concentration is simply computed on the basis of scavenging efficiency and Henry's law of equilibrium.

A better knowledge of relationships that relate solute concentration in cloud water to environmental parameters, as well as more data on the temporal variation of chemical concentration of cloud water, would clearly contribute to the construction of cloud chemistry models that possess better constraints. The goal of this paper is to provide information on atmospheric chemistry in the liquid phase in relation to the chemical and physical properties of aerosol particles and to the microphysics of clouds. We investigate cloud chemistry and present statistics that are based on the monitoring of sixteen cloud events during the winter/spring periods in two 
consecutive years. The chemical investigation includes measurements of inorganic compounds, as well as dissolved total organic carbon that includes speciation of organic carbon for many carboxylic acids. These measurements can provide the requisite data-set for the construction of models concerning cloud effects in the arena of tropospheric chemistry.

\section{Experimental}

\subsection{Study area and experimental set-up}

Experimental studies were carried out at the Puy de Dôme (PDD) station $\left(48^{\circ} \mathrm{N}, 2^{\circ} \mathrm{E} ; 1465 \mathrm{~m}\right.$ a.s.1.), in the Massif Central Region (France). It is a strategic point from which to observe warm and mixed clouds that are present $50 \%$ of the time between November and March. Clouds are frequently formed at the top of the site, either during advection of frontal systems or by the orographic rising of moist air. During the winter/spring months, the station lies in the free troposphere, as indicated by the low particle number concentration, and air masses are usually exempt from the influence of local pollution. Road access to the site was restricted to authorized personnel during all sampling periods; cars were stopped $5 \mathrm{~km}$ before the summit at $850 \mathrm{~m}$ a.s.l. to prevent local contamination. A small military base is located to the north of the station, but fuel combustibles are limited exclusively to winter storm events.

Meteorological parameters are monitored at the station and include wind speed and direction, temperature, pressure, and relative humidity ( $\mathrm{RH})$. In addition, monitoring of a variety of atmospheric gas concentrations $\left(\mathrm{O}_{3}, \mathrm{NO}_{\mathrm{x}}, \mathrm{SO}_{2}\right.$, $\mathrm{CO}_{2}$ ), black carbon (BC, measured by a Magee Scientific æthalometer, AE1-series), and total particle number concentrations $\left(\mathrm{N}_{\mathrm{CPC}}\right.$, measured in the range from $10 \mathrm{~nm}$ to $3 \mu \mathrm{m}$ by a Condensation Particle Counter Model 3010, product by TSI) occurs throughout the year. The station is equipped for cloud microphysical measurements. However, in this study we only have measurements of LWC and effective radius $(\mathrm{Re})$ of droplets as obtained with a Gerber PVM-100 probe. An overall description of measurements performed at the station can be found at http://www.obs.univ-bpclermont. fr/observ/chimie/pdd_listedata.html.

\subsection{Cloud droplets and aerosol particle sampling}

In addition to the routine monitoring described above, cloud sampling was performed between 8 February and 6 April 2001 (68 samples during 8 different events), and between 14 February and 12 May 2002 (10 samples during 8 different events) (see Table 1). The air mass origin, computed by backtrajectory analysis, is indicated for each cloud event. The sampling periods included both warm and super-cooled conditions for cloud droplets. Sampling was restricted to nonprecipitating clouds.
Cloud droplets were sampled with single-stage cloud collector similar to that described by Kruisz et al. (1993). Droplets are sampled at a flow rate of approximately $80 \mathrm{~m}^{3} \mathrm{~h}^{-1}$ and collected by impaction onto a $10 \mathrm{~cm}^{2}$ rectangular plate. The cloud droplets either freeze upon impact (super-cooled conditions) or are collected directly in the liquid phase. The droplet sampling efficiency is enhanced with the utilization of a large stagnation plate close to the collector inlet. Laboratory tests have shown that the cut-off diameter of the collector is approximately $7 \mu \mathrm{m}$. Changes in the cutoff diameter due to building of ice onto the impaction plate are expected to be small given the limited volume of collected sample.

Averaged droplet size distributions measured by a Forward Scattering Spectrometer Probe show that this cut-off is sufficient to collect more than $80 \%$ of the cloud liquid water mass (Dupuy et al., 2002). The sampling intervals (40 min up to $2 \mathrm{~h}$ ) varied and were dependent on the LWC. Previous experiments have shown that the LWC is measured with a precision of approximately 20\% (Mertes et al., 2001).

We concurrently used two collectors for sample analysis by ion chromatography and carbon. The difference between the samplers is in the material used for the impaction plates and the liquid water collectors, as well as the cleaning procedures. The sampler used for ion chromatography analysis and $\mathrm{pH}$ measurements was made of aluminium. The second sampler, used for total carbon (TC) and organic carbon (OC) analyses, was made of stainless-steel. Cleaning procedures were similar to those described by Sellegri et al. (2003b).

The samples for ion chromatography and carbon analyses were frozen immediately after collection, stored in glass bottles (Schott), and thawed in a clean room just before the analysis. IC and TC/OC measurements were performed within three days after collection.

Aerosol particles were sampled using 2 cascade impactors almost simultaneously with the collection of cloud water (see Table 1). Data are discussed by Sellegri et al. (2003a, b). Sampling is performed through a whole air inlet that collects both cloud droplets and interstitial particles. The sampling time required for aerosol collection is generally longer than the cloud sampling period for which an operator in needed. In addition, aerosol sampling is also performed in the absence of cloud. This explains the small differences in the sampling time of aerosols and clouds listed in Table 1. Gas phase concentrations of several species $\left(\mathrm{HNO}_{3}, \mathrm{SO}_{2}, \mathrm{NH}_{3}\right.$, $\mathrm{CH}_{3} \mathrm{COOH}, \mathrm{HCOOH}$ ) measured by mist chambers are also available for 2001 samples and are discussed by Sellegri et al. (2003c).

\subsection{Chemical analyses}

Aerosol and cloud samples were analysed for the determination of major ionic compounds, as well as total organic carbon concentrations. The preparation and analyses of the cloud and aerosol samples were performed under a class 100 
Table 2. Detection limits $\left(\mu \mathrm{g}^{-1}\right)$ for the chemical species measured by IC and for DOC under the analytical procedures used in this study, calculated like three times the standard deviation of field blank.

\begin{tabular}{cccccccc}
\hline Fluorure & Lactate & Acetate & Glycolate & Propionate & Formate & Glyoxylate & MSA \\
\hline 0.63 & 1.21 & 3.21 & 1.14 & 0.65 & 0.41 & 0.36 & 0.34 \\
\hline Nitrate & Glutarate & Succinate & Maleate & Malonate & Tartrate & Sulphate & Oxalate \\
\hline 0.11 & 0.56 & 0.98 & 0.64 & 1.01 & 0.26 & 0.66 & 0.98 \\
\hline Chloride & Sodium & Ammonium & Potassium & Magnesium & Calcium & DOC & \\
\hline 1.29 & 0.82 & 1.34 & 0.57 & 0.36 & 3.96 & 50 & \\
\hline
\end{tabular}

laminar flow bench to minimize possibility of contamination from external sources. Data quality was controlled utilizing two field blanks for each cloud event and one blank filter for every impactor.

\subsubsection{Ion chromatography}

Ion chromatographic analyses were performed in a clean room (class 10000). Cloud water was injected directly without filtration to avoid further contamination. Working conditions are similar to those detailed by Jaffrezo et al. (1998), who employed a DIONEX 100 chromatograph equipped with a CS12 column for the cations, and a DIONEX 500 with an AS11 column for the anions. $\mathrm{CH}_{3} \mathrm{COO}^{-}, \mathrm{HCOO}^{-}, \mathrm{Cl}^{-}$, $\mathrm{NO}_{3}^{-}, \mathrm{SO}_{4}^{2-}, \mathrm{C}_{2} \mathrm{O}_{4}^{2-}, \mathrm{Na}^{+}, \mathrm{NH}_{4}^{+}, \mathrm{K}^{+}, \mathrm{Mg}^{2+}$ and $\mathrm{Ca}^{2+}$ are the ions analysed in 2001. At the end of 2001 and in 2002, additional mono and di-carboxylic acids were measured: lactic, glycolic, propionic, glyoxylic, glutaric, succinic, maleic, malonic and tartaric. Detection limits were calculated from a mean blank plus one standard deviation. The accuracy of ion chromatographic analyses is typically $10 \%$ for samples 10 times the detection limit, and approximately 50\% for samples twice the detection limit. Detection limits are provided in Table 2.

\subsubsection{Dissolved organic carbon}

Dissolved Organic Carbon (DOC) measurements in the liquid phase were obtained with a Total Organic Carbon (TOC) analyzer Shimadzu model TOC-505OA on filtered samples. The Shimadzu TOC-505OA is capable of performing Total Carbon (TC) analyses by combustion and Inorganic Carbon (IC) analyses by oxidation. TOC measurements were obtained by calculating the difference between TC and IC measurements.

The instrument works with a TC combustion tube, which is filled with a TC catalyst and heated to $680^{\circ} \mathrm{C}$. When the cloud water sample is introduced into the TC combustion tube, the carbon is combusted/oxidized to form $\mathrm{CO}_{2}$. The carrier gas (purified air) and the combustion product $\left(\mathrm{CO}_{2}\right)$ pass through a sample cell of the Non-Dispersive Infrared Detector (NDIR), where $\mathrm{CO}_{2}$ is detected. For IC measure- ments, the sample is introduced into the IC reaction vessel (containing $\mathrm{H}_{3} \mathrm{PO}_{4} 25 \%$ ), through which the carrier gas flows in the form of tiny bubbles. Only the IC component in the sample is decomposed to form $\mathrm{CO}_{2}$, which is detected upon reaching the NDIR. In these conditions, Carbon in the form of carbonates and hydrogen carbonates are the only species measured as IC. Calibration curves within the range $0-15 \mathrm{mg} \mathrm{l}^{-1}$ were obtained by using potassium hydrogen phthalate and sodium hydrogen carbonate as representatives of organic and inorganic carbon respectively. Detection limits are provided in Table 2.

\section{Results}

\subsection{Chemical composition of the liquid phase}

\subsubsection{Inorganic substances}

The chemical analyses and microphysics data are reported in Table 3. We found large differences in the chemical composition of cloud water between events, both in relative composition and in total ionic content leading to concentration differences exceeding a factor of 100 for some compounds when comparing minimum and maximum values. This is not seen, however, within a single cloud event: half of the events are composed of more than one sample (Table 1) and no large variation in solute concentration is observed amongst samples of a same event.

The variations in solute concentrations are not due to variations in $\mathrm{LWC}\left(\mathrm{R}^{2} \mathrm{TIC} / \mathrm{LWC}=0.09\right)$. Because of limited variation of LWC, the cloud water loading (CWL) shows a similar behaviour to that of total ionic content (TIC).

The total ionic content (TIC) ranged from 0.7 to $199 \mathrm{mg} \mathrm{l}^{-1}$, with a median of $11 \mathrm{mg} \mathrm{l}^{-1}$ and a standard deviation of $27 \mathrm{mg} \mathrm{l}^{-1}$. The frequency distribution of total ionic content is shown in Fig. 1. The TIC average $\left(18 \mathrm{mgl}^{-1}\right)$ is driven by a few highly concentrated samples that reach $200 \mathrm{mg} \mathrm{l}^{-1}$, while the majority of samples have a TIC lower than $10 \mathrm{mgl}^{-1}$. These low concentrations are characteristic of European high-altitude sites, far from local pollution sources, such as Sonnblick (3106 ma.s.l., Austria, 
Table 3. Minimum, average, median, $25^{\circ}$ and $75^{\circ}$ percentile, and maximum of the chemical, physical and microphysical parameters measured at PDD station (Re: effective radius of droplets; $\mathrm{N}_{\mathrm{CPC}}$ : number of particles). Statistical parameters are calculated on all data set (78 samples).

\begin{tabular}{|c|c|c|c|c|c|c|c|}
\hline & MINIMUM & $25^{\circ}$ centile & AVERAGE & MEDIAN & $75^{\circ}$ centile & MAXIMUM & $\mathrm{N}^{\circ}$ samples \\
\hline Fluorure $\left(\mu \mathrm{g}^{-1}\right)$ & 2 & 6 & 9 & 7 & 9 & 31 & 15 \\
\hline Lactate $\left(\mu \mathrm{g} \mathrm{l}^{-1}\right)$ & 20 & 59 & 129 & 79 & 156 & 514 & 15 \\
\hline Acetate $\left(\mu \mathrm{g} \mathrm{l}^{-1}\right)$ & 37 & 186 & 494 & 304 & 591 & 2873 & 78 \\
\hline Glycolate $\left(\mu \mathrm{g} \mathrm{l}^{-1}\right)$ & $<\mathrm{DL}$ & 26 & 86 & 58 & 102 & 753 & 78 \\
\hline Propionate $\left(\mu \mathrm{g} \mathrm{l}^{-1}\right)$ & $<\mathrm{DL}$ & 18 & 54 & 33 & 53 & 600 & 78 \\
\hline Formate $\left(\mu \mathrm{g}^{-1}\right)$ & 37 & 151 & 447 & 257 & 464 & 3213 & 78 \\
\hline Glyoxylate $\left(\mu \mathrm{g} 1^{-1}\right)$ & $<\mathrm{DL}$ & 3.6 & 93 & 10 & 24 & 638 & 15 \\
\hline MSA $\left(\mu \mathrm{g} \mathrm{1^{-1 } )}\right.$ & $<\mathrm{DL}$ & 9.0 & 26 & 17 & 34 & 133 & 68 \\
\hline Chloride $\left(\mu \mathrm{g} \mathrm{l}^{-1}\right)$ & 17 & 232 & 2108 & 706 & 1497 & 69088 & 78 \\
\hline Nitrite $\left(\mu \mathrm{g} \mathrm{l}^{-1}\right)$ & 1 & 11 & 28 & 21 & 44 & 128 & 78 \\
\hline Nitrate $\left(\mu \mathrm{g}^{-1}\right)$ & 209 & 1375 & 6416 & 3116 & 7457 & 47539 & 78 \\
\hline Glutarate $\left(\mu \mathrm{g}^{-1}\right)$ & 7 & 16 & 81 & 29 & 63 & 337 & 15 \\
\hline Succinate $\left(\mu \mathrm{g} 1^{-1}\right)$ & 7 & 24 & 127 & 64 & 122 & 473 & 15 \\
\hline Maleate $\left(\mu \mathrm{g} \mathrm{l}^{-1}\right)$ & $<\mathrm{DL}$ & 6 & 37 & 19 & 36 & 180 & 15 \\
\hline Malonate $\left(\mu \mathrm{g}^{-1}\right)$ & $<\mathrm{DL}$ & 17 & 97 & 60 & 113 & 405 & 15 \\
\hline Tartrate $\left(\mu \mathrm{g}^{-1}\right)$ & $<\mathrm{DL}$ & 2 & 20 & 7 & 15 & 122 & 15 \\
\hline Sulphate $\left(\mu \mathrm{g} \mathrm{l}^{-1}\right)$ & 187 & 1107 & 4083 & 2897 & 4863 & 35499 & 78 \\
\hline Oxalate $\left(\mu \mathrm{g} \mathrm{l}^{-1}\right)$ & 8 & 65 & 164 & 109 & 164 & 1529 & 78 \\
\hline Sodium $\left(\mu \mathrm{g}^{-1}\right)$ & $<\mathrm{DL}$ & 115 & 659 & 299 & 691 & 6447 & 78 \\
\hline Ammonium $\left(\mu \mathrm{g}^{-1}\right)$ & 113 & 853 & 2652 & 1516 & 2676 & 32413 & 78 \\
\hline Potassium $\left(\mu \mathrm{g}^{-1}\right)$ & 5 & 51 & 176 & 88 & 142 & 4847 & 78 \\
\hline $\operatorname{Magnesium}\left(\mu \mathrm{g} \mathrm{1^{-1 }}\right)$ & 5 & 24 & 140 & 71 & 151 & 1109 & 78 \\
\hline Calcium $\left(\mu \mathrm{g}^{-1}\right)$ & 12 & 66 & 292 & 147 & 254 & 2994 & 78 \\
\hline DOC $\left(\mu \mathrm{g}^{-1}\right)$ & 1200 & 2100 & 5784 & 3630 & 7680 & 15460 & 17 \\
\hline pH (pH units) & 3.90 & 4.99 & 5.29 & 5.18 & 5.67 & 7.00 & 32 \\
\hline $\mathbf{T}\left({ }^{\circ} \mathrm{C}\right)$ & -5.96 & -5.17 & -2.02 & -1.13 & -0.59 & 8.90 & 73 \\
\hline $\mathbf{L W C}\left(\mathrm{g} \mathrm{m}^{-3}\right)$ & 0.06 & 0.19 & 0.27 & 0.25 & 0.32 & 0.58 & 68 \\
\hline $\mathbf{N}_{\mathrm{CPC}}\left(\# \mathrm{~cm}^{-3}\right)$ & 409 & 649 & 1387 & 1134 & 1602 & 4193 & 40 \\
\hline $\operatorname{Re}(\mu \mathrm{m})$ & 0.9 & 3.3 & 3.9 & 3.7 & 4.5 & 7.0 & 68 \\
\hline
\end{tabular}

Hitzenberger et al., 2000; Kasper-Giebl et al., 2000) and Jungfraujoch (3450 m a.s.1, Switzerland, Baltensperger et al., 1998). Most cloud samples with low concentration were sampled during winter (January-February) and showed a strong decoupling between free-tropospheric and boundary layer air masses, even at the relatively low altitude of PDD. This is confirmed by the low concentration of particle number at the station in winter/spring time (more than $72 \%$ of the time the number of particles $\mathrm{cm}^{-3}$ is below 2000).

As shown by the frequency distribution in Fig. 1, a consistent fraction of cloud samples have consistent solute concentrations between 18 and $50 \mathrm{mgl}^{-1}$. These concentrations are slightly lower than ionic concentrations measured at mountain sites under the influence of medium range pollution, such as Great Dun Fell (23 $\mathrm{mg}^{-1}$ just for sulphate, Laj et al., 1997b), Aubure in the Vosges Mountains (eastern France; $66 \mathrm{mg}^{-1}$ measured by Herckes et al., 2002), Whiteface Mountain (60 $\mathrm{mgl}^{-1}$ Khwaja et al., 1995) and the eastern part of United States (Weathers al., 1988). This also corresponds to the range of concentrations found during the CIME campaign, and to levels measured by Voisin et al. (2000) at PDD. The long-range transport of atmospheric pollutants, mostly from northern Europe, can have a substantial impact on the chemistry of clouds during several events.

Finally, the presence of highly concentrated samples is surprising for such a non-industrialized area. These concentrations are in fact similar to those found in the much polluted regions of the Po Valley $\left(211 \mathrm{mg} \mathrm{l}^{-1}\right.$, Fuzzi et al., 1988) and the Czech Krusne Hory plateau $\left(120 \mathrm{mg} \mathrm{l}^{-1}\right.$, Bridges et al. 2002). Similar elevated levels were already encountered at PDD during a cloud event of the CIME campaign (59 $\mathrm{mg} \mathrm{l}^{-1}$, Flossmann, 2000).

Variation of cloud TIC is paralleled with variation in the concentration of the relative chemical components of cloud water. As expected, nitrate, sulphate and ammonium are the most abundant ions in cloud water at the PDD site. $\mathrm{NO}_{3}^{-}$ 


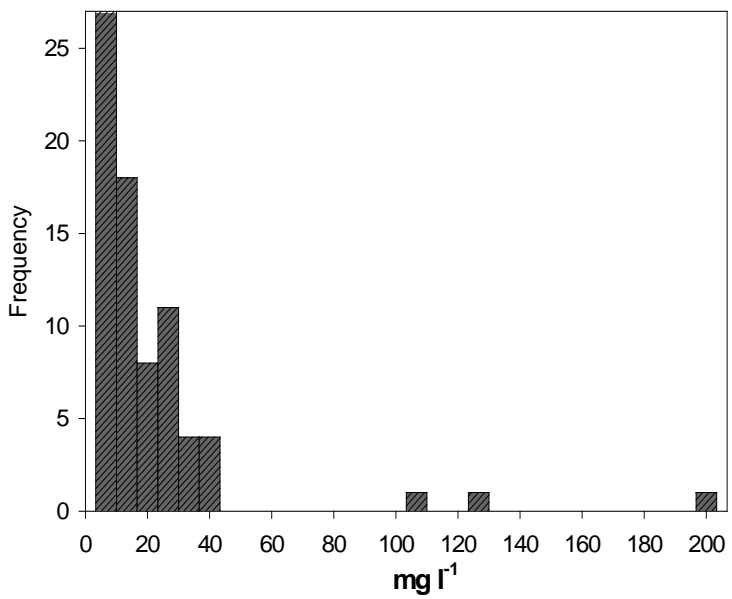

Fig. 1. Frequency distribution of Total Ionic Content in cloud water samples.

is the most important anion with an average contribution to the TIC of $37 \%$; concentrations range from $0.2 \mathrm{mg}^{-1}$ to $47 \mathrm{mgl}^{-1}$, with a median of $3.1 \mathrm{mg}^{-1}$. The second most abundant anion is $\mathrm{SO}_{4}^{2-}\left(22 \%\right.$, ranging from $0.2 \mathrm{mg} \mathrm{l}^{-1}$ to $35 \mathrm{mg} \mathrm{l}^{-1}$ with a median of $2.9 \mathrm{mg} \mathrm{l}^{-1}$ ), followed by chloride $\left(9 \%\right.$, ranging from $0.02 \mathrm{mg}^{-1}$ to $69 \mathrm{mg} \mathrm{l}^{-1}$ with a median of $0.7 \mathrm{mg}^{-1}$ ) and organic acids $(9 \%$, ranging from $0.1 \mathrm{mg} \mathrm{l}^{-1}$ to $11 \mathrm{mg} \mathrm{l}^{-1}$ with a median of $\left.0.8 \mathrm{mg} \mathrm{l}^{-1}\right)$. $\mathrm{NH}_{4}^{+}$ is the most abundant cation (13\%, ranging from $0.1 \mathrm{mg}^{-1}$ to $32 \mathrm{mg} \mathrm{l}^{-1}$ with a median of $1.5 \mathrm{mg} 1^{1}$ ), followed by sodium ( $4 \%$, ranging from $0.01 \mathrm{mgl}^{-1}$ to $6.4 \mathrm{mgl}^{-1}$ with a median of $0.3 \mathrm{mg}^{-1}$ ) and minor contributions from the others cations.

A striking difference between the cloud chemistry measured at PDD and that of previous studies at other locations is the predominant contribution of nitrate to the TIC. For example, sulphate is on average 32 times more concentrated in the Po Valley than at PDD, while nitrate is just 12 times more concentrated, despite the presence of important nitrogen emissions. The remoteness from local sources and the efficient oxidation of $\mathrm{NO}_{\mathrm{x}}$ make nitrate a key substance that drives the chemistry of clouds at the PDD site.

Consequently, the acidity of cloud water is controlled by both nitrate and sulphate. The $\mathrm{pH}$ of cloud water was not measured in every sample, but it can be estimated by the ionic balance. The liquid phase often shows cation-to-anion ratios that are below unity, indicating that these samples are quite acidic. The average ratio is 0.87 (in equivalents), with lowest values occurring in the most concentrated events: \#3 (0.65), \#14 (0.69) and \#5 (0.74), with two samples of the latter also having the lowest measured $\mathrm{pH}$ values (4.1 in event \#3 and 4.8 in event \#5). In contrast, in samples at low concentrations $\mathrm{NH}_{4}^{+}$present in solution is sufficient to neutralize the acidity from both $\mathrm{HNO}_{3}$ and $\mathrm{H}_{2} \mathrm{SO}_{4}$. The presence of relatively high ammonia/ammonium concentrations appears consistently at

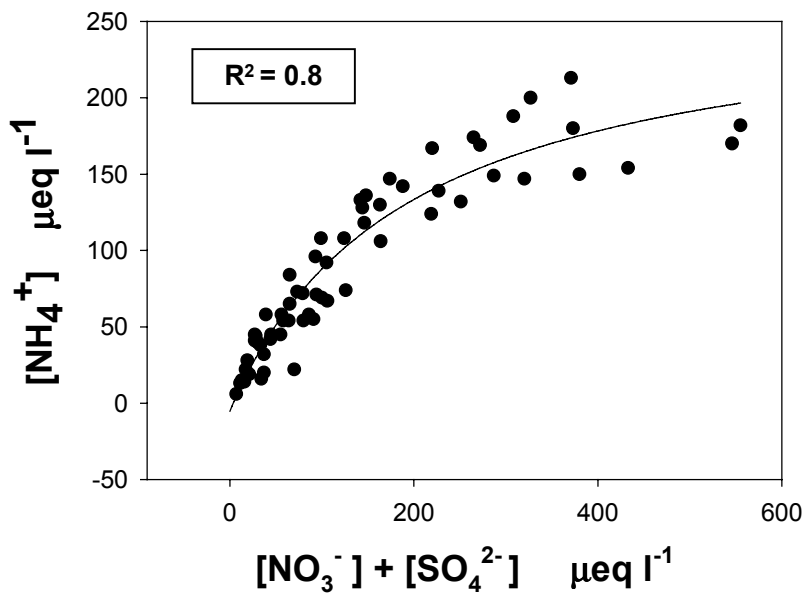

Fig. 2. Correlation between ionic concentration of the major acidifying species $\left(\mathrm{NO}_{3}^{-}\right.$and $\left.\mathrm{SO}_{4}^{2-}\right)$ and ammonium in cloud water.

PDD, even during wintertime. The average $\left(\mathrm{NH}_{3}+\mathrm{NH}^{4+}\right)$ concentration monitored for the 2001 samples is of the order of $1 \mu \mathrm{g} \mathrm{m}^{-3}$ (Sellegri et al., 2003c). A large fraction of $\mathrm{NH}_{4}^{+}$arises from the dissolution of gaseous $\mathrm{NH}_{3}$ (Sellegri et al., 2003c; Laj et al., 2001). The acidity of cloud water in the background continental free troposphere is influenced by emissions from agricultural activities on the regional scale. Background $\mathrm{NH}_{3}$ levels are not sufficient to neutralize cloud water during advection of anthropogenic air masses.

The progressive decrease of the contribution of $\mathrm{NH}_{4}^{+}$to TIC as a function of the anthropogenic character of airmasses $\left(\mathrm{SO}_{4}^{2-}+\mathrm{NO}_{3}^{-}\right)$is illustrated in Fig. 2. Nitrate and sulphate are significantly correlated with $\mathrm{NH}_{4}^{+}\left(\mathrm{R}^{2}=0.80\right)$, but the acidic behaviour of air masses is controlled by $\mathrm{NO}_{3}^{-}$. The average nitrate to sulphate equivalent ratio is 1.28 , and is higher than ratios obtained for cloud water samples collected at Whiteface Mountain (Khwaja et al., 1995) or at various sites in the United States (Weathers et al., 1988), where the ratio ranged from 0.13 to 0.53 . However, a similar ratio of 1.1 was found by Löflund et al. (2002) at Mount Rax (Austria, $1400 \mathrm{~m}$ a.s.l.). The nitrate to sulphate ratio has been used as an indicator of the remoteness of a site by Weathers et al. (1988); indeed a value of 0.53 was found in the Czech Krusne Hory plateau (Bridges et al., 2002), 0.6 in the Vosges Mountains (Herckes et al., 2002) and 0.72 at Jungfraujoch (Baltensperger et al., 1998): the nitrate to sulphate ratio clearly increases with remoteness of the sampling site. This is not the case at PDD, where high nitrate fractions are associated with anthropogenic air masses. Sellegri et al. (2003a) reached similar conclusions from the aerosol composition at PDD. A ratio of 0.94 was also measured by the CIME experiment during a highly polluted episode (Flossmann, 2000). The predominance of nitrate over sulphate in the acidification of aerosols has already been observed over Europe (Schaap et al., 2002), and might indicate an evolution of the sources of 


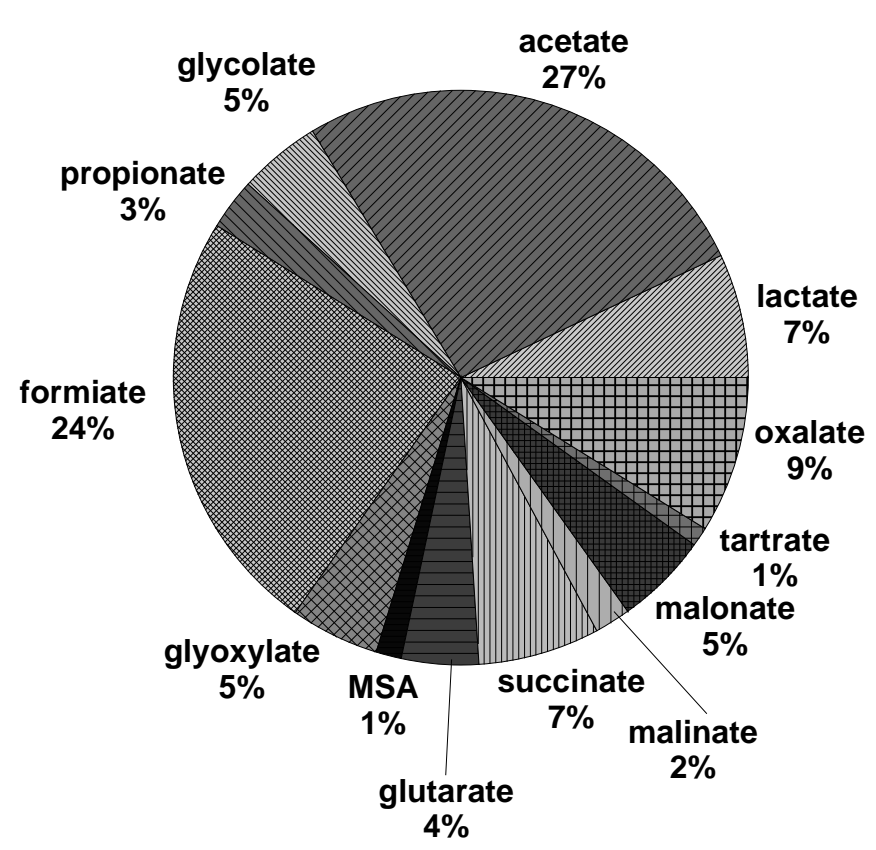

Fig. 3. Contribution of different carboxylic acids to the cloud droplets composition (average on 16 events).

pollution. The data considered from Europe are more recent than that from the USA, and may indicate both a change in emission characteristics and differences in rate of emissions between Europe and the USA.

\subsubsection{Organic species}

Dissolved Organic Carbon (DOC) was measured on 7 samples in 2001 and 10 samples in 2002. The concentration of DOC ranges from $1.2 \mathrm{mgl}^{-1}$ to $8.9 \mathrm{mg}^{-1}\left(15.4 \mathrm{mg} \mathrm{l}^{-1}\right.$ for event \#14), with a median of $3.6 \mathrm{mg}^{-1}$. These values are similar to levels measured in clouds at Mount Rax (Löflund et al., 2002). The correlation between DOC and TIC is significant $\left(R^{2}=0.78\right)$, although the relationship is characterized by significant scattering. Among the three major ionic species, the strongest correlation $\left(\mathrm{R}^{2}=0.86\right)$ is found with $\mathrm{NH}_{4}^{+}$, that derives from both anthropogenic and natural emissions, the weakest correlation occurs with $\mathrm{NO}_{3}^{-}$ $\left(\mathrm{R}^{2}=0.73\right)$. However, no significant correlation is found with $\mathrm{BC}$, a tracer for anthropogenic air masses; this is contrary to the findings of Löflund et al. (2002) who found that an increase in $\mathrm{BC}$ concentrations coincided with elevated organic acid concentrations of various acids, especially during several events. On the other hand, very high levels of DOC can be found in clouds in the presence of polluted air masses, accompanied by a characteristic high TIC (up to $15 \mathrm{mg} \mathrm{l}^{-1}$ ) and high levels of $\mathrm{N}_{\mathrm{CPC}}$. These results may indicate that a fraction of the DOC is not associated with the long-range transport of anthropogenic air masses, but rather with non-
Table 4. $\mathrm{HCOO}^{-} / \mathrm{SO}_{4}^{2-}, \mathrm{CH}_{3} \mathrm{COO}^{-} / \mathrm{SO}_{4}^{2-}$ and $\mathrm{C}_{2} \mathrm{O}_{4}^{2-} / \mathrm{SO}_{4}^{2-} \mathrm{ra}-$ tios during daytime and nighttime.

\begin{tabular}{lccc}
\hline & $\begin{array}{c}\text { Formate/ } \\
\text { sulphate }\end{array}$ & $\begin{array}{c}\text { Acetate/ } \\
\text { sulphate }\end{array}$ & $\begin{array}{c}\text { Oxalate/ } \\
\text { sulphate }\end{array}$ \\
\hline Daytime & 0.21 & 0.22 & 0.06 \\
Nighttime & 0.10 & 0.14 & 0.03 \\
\hline
\end{tabular}

urban sources that are possibly biogenic or agricultural in origin. We estimate this background level at the PDD to be between 2 and $3 \mathrm{mg} \mathrm{l}^{-1}$, and it is quite constant in all low concentrated clouds. In the case of polluted events, a further anthropogenic source of organic carbon can be superimposed on the background level. This is confirmed by the correlation between DOC and $\mathrm{N}_{\mathrm{CPC}}$ that is weak $\left(\mathrm{R}^{2}=0.37\right)$ on whole data set, but it becomes significant in polluted air masses $\left(\mathrm{R}^{2}=0.8\right.$ during event \#14). Unfortunately, data correlating $\mathrm{BC}$ and $\mathrm{DOC}$ have not been available for polluted air masses for some time.

A significant fraction of the DOC is measured with ion chromatography. Overall, the carboxylic acids contribution to the DOC ranges from $18 \%$ to $71 \%$, with an average of $36 \%$. Khwaja et al. (1995) attributed $7-15 \%$ of the DOC to acetic, formic, oxalic, malonic and pyruvic acids in cloud water on Whiteface Mountain.

A large fraction of the $\mathrm{CA}$ are monocarboxylic acids: the mono-carboxylic acids (MCA: formic, acetic, lactic, glycolic, glyoxylic, propionic) are present in larger concentrations (71\% of the CA concentration) than the dicarboxylic acids (DCA: oxalic, glutaric, succinic, maleic, malonic and tartaric) (29\% of the CA concentration). The oxalic acid (9\%) is the most abundant DCA. As shown in Fig. 3, the most abundant carboxylic acids are acetic (27\%) and formic (24\%). This is in agreement with Chebbi and Carlier (1996) who showed that formic and acetic acids are the predominant $\mathrm{CA}$ in the tropospheric aqueous phase.

However, the contribution of organic acids to the total solute content remains low compared to the contribution of major ions, varying from $2 \%$ to $25 \%$ and showing an average of $10 \%$. This corresponds to concentrations ranging from $0.1 \mathrm{mgl}^{-1}$ to $5.3 \mathrm{mg} \mathrm{l}^{-1}$, with a median of $0.7 \mathrm{mg} \mathrm{l}^{-1}$ and a noteworthy maximum concentration in event \#14 of $11 \mathrm{mg} \mathrm{l}^{-1}$. The acetic, formic and oxalic acid concentrations are twice those measured at PDD by Voisin et al. (2000), but in the same range as those recorded at Mount Rax (Löflund et al., 2002) and Mount Sonnblick (Brantner et al., 1994; Limbeck and Puxbaum, 2000).

The contribution of organic acids to ionic composition decreases with an increase in the anthropogenic character of the air mass. It varies from more than $20 \%$ in samples with solute content $<18 \mathrm{mgl}^{-1}$ to less than $5 \%$ for heavily concentrated samples. As seen by Sellegri et al. (2003c), the 

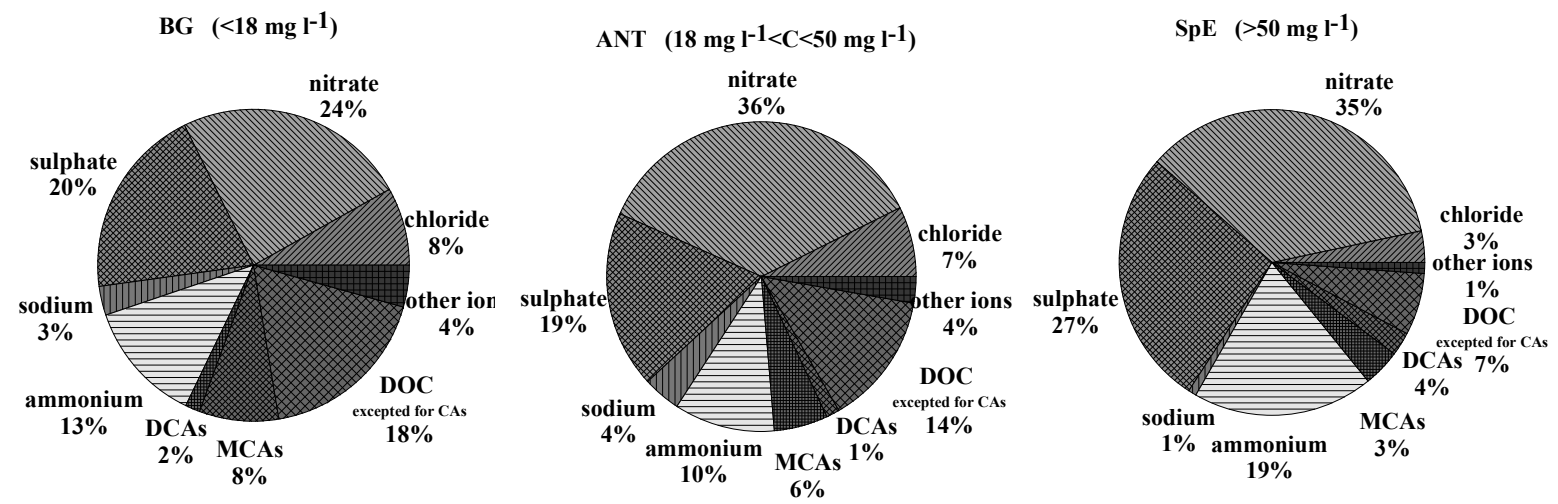

Fig. 4. Cloud water composition (in $\mathrm{mg}^{-1}$ ) for ionic and organic compounds for the three different types of cloud event at PDD.

most common CAs are originating principally from the gasphase. The CA have $\mathrm{pK}_{a}$ values that fall within typical $\mathrm{pH}$ values for cloud water (acetic acid 4.75), and thus their dissolution, depending upon $\mathrm{pH}$, can be reduced by low $\mathrm{pH}$ during polluted events. This is in contrast to the dissolution of $\mathrm{NH}_{3}$ which is not $\mathrm{pH}$ dependent when $\mathrm{pH}$ values are below 9 units. Although we cannot exclude, at this point, that low concentrations of $\mathrm{CA}$ are regulated by weaker solubilisation of $\mathrm{CA}$ at low $\mathrm{pH}$, we propose that similarities between $\mathrm{CA}$ and $\mathrm{NH}_{4}^{+}$indicate that a large fraction of both species originates from non-urban sources. In addition, contrary to the findings of Löflund et al. (2002) at Mount Rax, a good correlation $\left(\mathrm{R}^{2}=0.87\right)$ between DOC and the sum of organic acids is found at PDD. We can conclude that background CA levels in the continental free troposphere most likely originate from biogenic sources and they may be used as tracer components for the DOC in cloud water, and vice versa.

Several samples were taken during night-time. An interesting feature of the cloud chemistry is that the $\mathrm{HCOO}^{-} / \mathrm{SO}_{4}^{2-}, \mathrm{CH}_{3} \mathrm{COO}^{-} / \mathrm{SO}_{4}^{2-}$ and $\mathrm{C}_{2} \mathrm{O}_{4}^{2-} / \mathrm{SO}_{4}^{2-}$ ratios appear consistently higher during the daytime than the nighttime (Table 4). This is seen both when samples are considered as independent variables or averaged on a per-event basis. The daytime/night-time difference is significant at the 95\% confidence level. This leads to the conclusion that a fraction of the carboxylic acids, including oxalate, are produced via photochemical reactions, either in the gas or liquid phase of clouds, as proposed by Chebbi and Carlier (1996).

\subsection{Composition of clouds in the continental free tropo-} sphere

Following the approach of Sellegri et al. (2003a), we have attempted a classification of clouds on the basis of their TIC to differentiate solute chemical composition for background continental (BG), anthropogenic-influenced (ANT) and polluted conditions (SpE). Based on comparisons with previous studies performed in remote conditions and on the shape of the frequency distribution of Fig. 1, we have set the TIC threshold for background continental conditions to $15 \mathrm{mgl}^{-1}$. Based on the same arguments, the TIC threshold for anthropogenic-influenced cloud composition is set to $40 \mathrm{mg} \mathrm{l}^{-1}$.

Taking into account the organic fraction of dissolved material, the concentration thresholds for the different categories are:

- Background continental free troposphere: solute concentration $<18 \mathrm{mg} \mathrm{l}^{-1}$

- Anthropogenic-influenced: $18 \mathrm{mg}^{-1}<$ solute concentration $<50 \mathrm{mg} \mathrm{l}^{-1}$

- Polluted: solute concentration $>50 \mathrm{mg} \mathrm{l}^{-1}$

The overall composition comparison between the three cloud types leads to an average composition of cloud water for the three different air mass categories, as shown in Fig. 4. The average of the most important chemical species and the ratios discussed previously are shown in Table 5 .

The major difference between the three categories is due to the decrease in the contribution of DOC to the solute concentration: $28 \%$ for background conditions, $21 \%$ for anthropogenic-influenced air masses, and $13 \%$ for polluted cases. The CA contribution to DOC also decreases as the anthropogenic influence increases. Marine species $\mathrm{Na}^{+}$and $\mathrm{Cl}^{-}$) show the same behaviour as the organic compounds: they account for $11 \%$ in background conditions and decrease to only $4 \%$ in polluted cases. This is paralleled with an increase in the $\mathrm{NO}_{3}^{-}$contribution, from $24 \%$ in background conditions up to $35 \%$ for both polluted and anthropogenic influenced conditions. The high levels of $\mathrm{NH}_{4}^{+}$during polluted cases show that these events are associated with strong transport from the boundary layer where $\mathrm{NH}_{3}$ emissions take place. Regardless of the conditions, the contribution of $\mathrm{SO}_{4}^{2-}$ remains lower than that of $\mathrm{NO}_{3}^{-}$and never exceeds $20 \%$, except for the polluted event \#14 where it reached $27 \%$. The changes in chemical composition are followed by changes in cloud acidity, with a decrease in $\mathrm{pH}$ from a 
Table 5. Averaged values for three different air mass categories (in $\mu \mathrm{g}^{-1}$ when not specified).

\begin{tabular}{|c|c|c|c|c|c|c|}
\hline & \multicolumn{2}{|r|}{ BG } & \multicolumn{2}{|r|}{ ANT } & \multicolumn{2}{|r|}{ SpE } \\
\hline & Average & Standard deviation & Average & Standard deviation & Average & Standard deviation \\
\hline chloride & 703 & 1220 & 2146 & 2228 & 25670 & 37672 \\
\hline nitrate & 2125 & 1408 & 10702 & 6631 & 42236 & 5465 \\
\hline sulphate & 1765 & 1342 & 5460 & 1584 & 31922 & 3125 \\
\hline sodium & 274 & 379 & 1175 & 1331 & 2530 & 2679 \\
\hline ammonium & 1102 & 633 & 3074 & 934 & 26023 & 5538 \\
\hline potassium & 70 & 46 & 172 & 116 & 2030 & 2451 \\
\hline magnesium & 94 & 189 & 221 & 223 & 125 & 73 \\
\hline calcium & 189 & 292 & 363 & 450 & 1414 & 1392 \\
\hline DOC (mg/l) & 2.75 & 1.65 & 6.12 & 2.57 & 15.46 & 1.55 \\
\hline MCA & 642 & 465 & 1466 & 1116 & 6202 & 2278 \\
\hline DCA & 82 & 50 & 250 & 151 & 2555 & 382 \\
\hline TIC $\left(\mathrm{mg} \mathrm{l}^{-1}\right)$ & 7.11 & 4.20 & 25.16 & 6.47 & 141.29 & 51.74 \\
\hline $\mathbf{N}_{\mathrm{CPC}}\left(\# \mathbf{c m}^{-3}\right)$ & 843 & 375 & 1837 & 792 & 4193 & \\
\hline pH & 5.27 & 0.28 & 5.09 & 0.95 & 5.90 & \\
\hline LWC $\left(\mathrm{g} \mathrm{cm}^{-3}\right)$ & 0.25 & 0.10 & 0.28 & 0.10 & 0.43 & \\
\hline $\mathbf{R}_{\mathrm{eff}}(\mu \mathbf{m})$ & 4.1 & 1.3 & 3.4 & 0.7 & 3.1 & 0.8 \\
\hline NO3/SO4 & 1.18 & 0.73 & 1.73 & 1.17 & 1.04 & 0.06 \\
\hline CA/DOC & 32.36 & 12.41 & 27.88 & 6.86 & 56.65 & 13.73 \\
\hline $\mathrm{Na} / \mathrm{Cl}$ & 0.84 & 0.59 & 0.85 & 0.49 & 0.30 & 0.15 \\
\hline
\end{tabular}

value of 5.5 during background periods to a value of 5.1 for anthropogenic-influenced cases. The $\mathrm{pH}$ difference between polluted episodes and anthropogenic-influenced air masses is of the order of $0.4 \mathrm{pH}$ units, and is primarily due to the addition of $\mathrm{HNO}_{3}$. In the special event \#14, nitrate and sulphate are the predominant ionic species but the $\mathrm{pH}$ remains fairly high ( $\mathrm{pH}=5.9)$, suggesting the efficient neutralization of acidity by large amounts of ammonium from the gas phase.

Such chemical changes in the liquid phase chemistry of clouds are of obvious importance for the dissolution and reaction rates of many chemical species.

\subsection{Relationship with the chemical composition of aerosol particles}

Sellegri et al. (2003a) have proposed a classification of the different aerosol types at PDD, giving an average aerosol composition for the three air mass types through the analysis of aerosol chemistry. Here, we have compared the relative composition of clouds and aerosols for the different air mass conditions. As aerosols and clouds are not always sampled simultaneously (the time integration of aerosol samples is much longer than that for clouds, and can take place during clear sky conditions), a comparison of average composition is not straightforward.

However, both classifications are performed on the basis of the ionic content of either cloud water or aerosols. We can check the consistency of the 2 classifications by converting the liquid phase concentration into an atmospheric con- centration (Cloud Water Load, CWL). This is simply computed using the average concentration of cloud water (LWC) as measured by the PVM probe:

$[\mathrm{CWL}]_{\mu \mathrm{g} \mathrm{m}^{-3}}=\frac{[\mathrm{TIC}]_{\mathrm{mg} 1^{-1}[\mathrm{LWC}]_{\mathrm{gm}^{-3}}}}{\rho_{\mathrm{gl}^{-1}}^{\text {water }}}$

The results of the comparison between the 2 classifications are shown in Table 6. Under the assumption that aerosol and cloud classes are referring to the same air masses (this is verified when cloud and aerosols are sampled simultaneously), it is clear that atmospheric concentration derived from cloud water is higher than the corresponding aerosol concentration. On average, the concentration in cloud is three times higher than that observed in the aerosol phase. This can result from (i) the limited sampling of the largest and less concentrated droplets that account for a non negligible fraction of the LWC, and (ii) the significant contribution from soluble gaseous compounds.

This last hypothesis is supported by a comparison of the average composition of cloud water and aerosol particles as shown in Fig. 5. The aerosol composition in this figure is derived from the results of Sellegri et al. (2003a). The most striking difference between aerosol and cloud compositions concerns the much larger contribution of organic carbon to the aerosol phase. On average, OC (including non-soluble OC) represents $45 \%$ of the total mass in the aerosol phase, while it accounts for just $23 \%$ in the aqueous phase. This difference is confirmed for the three air mass categories. As 
Table 6. Classification of cloud water and aerosol particles in free troposphere at PDD summit.

\begin{tabular}{|c|c|c|c|c|c|c|}
\hline \multicolumn{3}{|c|}{ Aerosol (Sellegri et al., 2003a) } & \multicolumn{4}{|c|}{ Cloud water (this work) } \\
\hline Label & $\begin{array}{l}\text { Thresholds } \\
\text { (ionic mass) }\end{array}$ & Description & Label & $\begin{array}{l}\text { thresholds } \\
\text { (ionic mass) }\end{array}$ & $\begin{array}{l}\text { Atmospheric } \\
\text { concentration }\end{array}$ & Description \\
\hline $\begin{array}{c}\text { Background } \\
\text { BG }\end{array}$ & $<1 \mu \mathrm{g} \mathrm{m}^{-3}$ & $\begin{array}{l}\text {-presence of sea salt } \\
\text {-neutral or alkaline } \\
\text {-relatively higher } \\
\text { OC content } \\
\text {-low EC/OC ratio }\end{array}$ & $\begin{array}{c}\text { Background } \\
\text { BG }\end{array}$ & $15 \mathrm{mg} \mathrm{l}^{-1}$ & $<4 \mu \mathrm{g} \mathrm{m}^{-3}$ & $\begin{array}{l}\text {-presence of sea salt } \\
\text {-low contribution of } \\
\text { nitrate and sulphate } \\
\text {-less acidic } \\
\text {-relatively higher DOC }\end{array}$ \\
\hline $\begin{array}{c}\text { Anthropogenic } \\
\text { ANT }\end{array}$ & $\begin{array}{c}1 \mu \mathrm{g} \mathrm{m}^{-3} \\
<\mathrm{C}< \\
5 \mu \mathrm{g} \mathrm{m}^{-3}\end{array}$ & $\begin{array}{l}\text {-abundance of nitrate, } \\
\text { sulphate and ammonium } \\
\text {-acidic } \\
\text {-OC less important } \\
\text {-higher EC/OC ratio }\end{array}$ & $\begin{array}{c}\text { Anthropogenic } \\
\text { influenced } \\
\text { ANT }\end{array}$ & $\begin{array}{c}15 \mathrm{mg} \mathrm{l}^{-1} \\
<\mathrm{C}< \\
40 \mathrm{mg} \mathrm{l}^{-1}\end{array}$ & $\begin{array}{c}4 \mu \mathrm{g} \mathrm{m}^{-3} \\
<\mathrm{C}< \\
15 \mu \mathrm{g} \mathrm{m}^{-3}\end{array}$ & $\begin{array}{l}\text { - abundance of nitrate } \\
\text {-more acidic } \\
\text {-DOC less important }\end{array}$ \\
\hline $\begin{array}{c}\text { Special Events } \\
\text { Continental } \\
\text { SpE }\end{array}$ & $>5 \mu \mathrm{g} \mathrm{m}^{-3}$ & $\begin{array}{l}\text { - one event at } 20 \mu \mathrm{g} \mathrm{m}^{-3} \\
\text { - low OC } \\
\text {-abundance of nitrate } \\
\text {-acidic }\end{array}$ & $\begin{array}{l}\text { Polluted } \\
\text { SpE }\end{array}$ & $>40 \mathrm{mg} \mathrm{l}^{-1}$ & $>15 \mu \mathrm{g} \mathrm{m}^{-3}$ & $\begin{array}{l}\text { •very high TIC }\left(160 \mathrm{mg} \mathrm{l}^{-1}\right) \\
\text {-abundance of nitrate, } \\
\text { sulphate and ammonium } \\
\text { ( } 82 \% \text { of solutes) } \\
\text { •low DOC contribution } \\
\text {-DCA more concentrated } \\
\bullet \text { MCA less concentrated }\end{array}$ \\
\hline $\begin{array}{l}\text { Special events } \\
\text { Saharan dust } \\
\text { SpE }\end{array}$ & $>5 \mu \mathrm{g} \mathrm{m}^{-3}$ & $\begin{array}{l}\bullet \text { very high dust, } \mathrm{Ca}^{++} \\
\text {and nssK }{ }^{+} \text {content } \\
\bullet \text { very low OC } \\
\bullet \text { abundance of nitrate }\end{array}$ & No occurrence & & & \\
\hline
\end{tabular}

shown by Sellegri et al. (2003b), the OC fraction of the aerosol is not scavenged efficiently by clouds. Moreover, both aerosol and cloud phases show a decrease in OC contribution with an increase in the degree of air mass pollution.

Another indication of the reduced $\mathrm{CCN}$ properties of organic aerosols is the fact that the contribution of ionic OC in the liquid phase is dominated by carboxylic acids, accounting for $36 \%$ of DOC. However, carboxylic acids account for less than $3 \%$ of OC in the aerosol phase, which corresponds to $8 \%$ of the total solute concentration in droplets and $1.2 \%$ of the total mass in the aerosol phase.

Among organic acids, oxalic acid is the most abundant in the aerosol phase $\left(22 \mathrm{ng} \mathrm{m}^{-3}, 52 \%\right.$ of total CA), followed by formic $\left(11 \mathrm{ng} \mathrm{m}^{-3}\right)$ and acetic $\left(2 \mathrm{ng} \mathrm{m}^{-3}\right)$, while formic and acetic acids are dominant in the cloud phase. Clearly, gasphase CA contribute to a large fraction of the OC present in the droplets.

Similarly, marine species are more concentrated in the liquid phase (11\% of the TIC) than in the aerosol phase (less than $5 \%$ of ionic mass). The high correlation coefficient between $\mathrm{Na}^{+}$and $\mathrm{Cl}^{-}\left(\mathrm{R}^{2}=0.98\right)$ and the molar ratio $\mathrm{Na} / \mathrm{Cl}$ of 0.81 (very close to 0.86 of sea water) confirms the marine origin of these species. The major difference between the 2 reservoirs may be due to the presence of dissolved $\mathrm{HCl}$ in droplets, as shown by Sellegri et al. (2003c): the lack of $\mathrm{Cl}$ in aerosol phase is due to evaporation of $\mathrm{Cl}$ in form of $\mathrm{HCl}$ and its solubilisation back in presence of liquid water.

Finally, as expected for species present in both the gas and aerosol phases, the contribution of $\mathrm{NO}_{3}^{-}$is higher in clouds (32\%) than in aerosols (13\%). An interesting feature is the fact that the contribution of gas-phase $\mathrm{NO}_{3}^{-}$to cloud water appears to be relatively higher for background samples than for anthropogenic samples. $\mathrm{NO}_{3 \text { cloud }}^{-} \mathrm{NO}_{3 \text { aerosol }}^{-}$decreases gradually from 2.9 in background conditions to 1.7 in anthropogenic samples, and to 1.0 in special events. The same trend from BG to ANT is exhibited for species that have a large gas phase fraction $\left(\mathrm{NH}_{4}^{+}\right.$from 3 to $1.4 ; \mathrm{SO}_{4}^{2-}$ from 1.4 to 0.7 ; CA vary less widely from 3 in $\mathrm{BG}, 2.8$ in ANT, and 2.7 in $\mathrm{SpE}$ ), while the sum of the other ions display an inverse trend (from 1.2 in BG to 1.6 in ANT and SpE).

\subsection{Relationship with cloud microphysics}

Möller et al. (1996), Elbert et al. (2000) and Kasper-Giebl et al. (2000) provided experimental support for early theoretical considerations concerning an inverse relationship between ionic content in cloud or fog water and the respective LWC (Junge, 1963). This does not appear to be the case in our study of cloud climatology. The cloud LWC at PDD does not show significant fluctuation, either within a single 

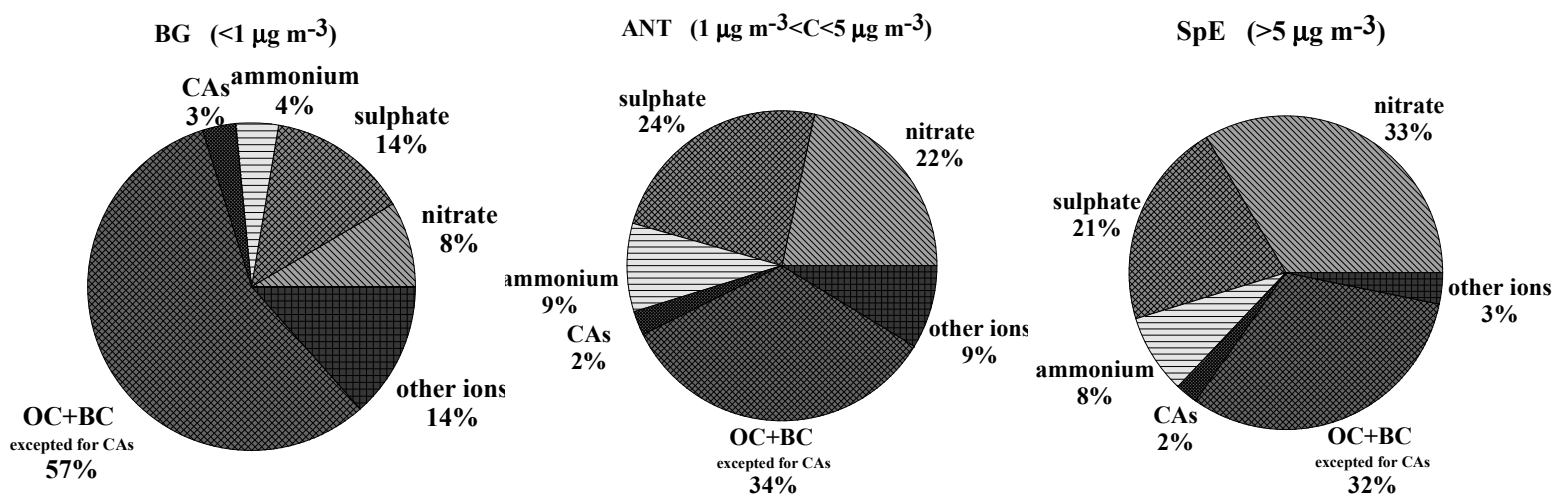

Fig. 5. Bulk aerosol composition (in $\mu \mathrm{g} \mathrm{m}^{-3}$ ) for ionic and organic compounds for the three different types of aerosol at PDD (modified from Sellegri et al., 2003a).
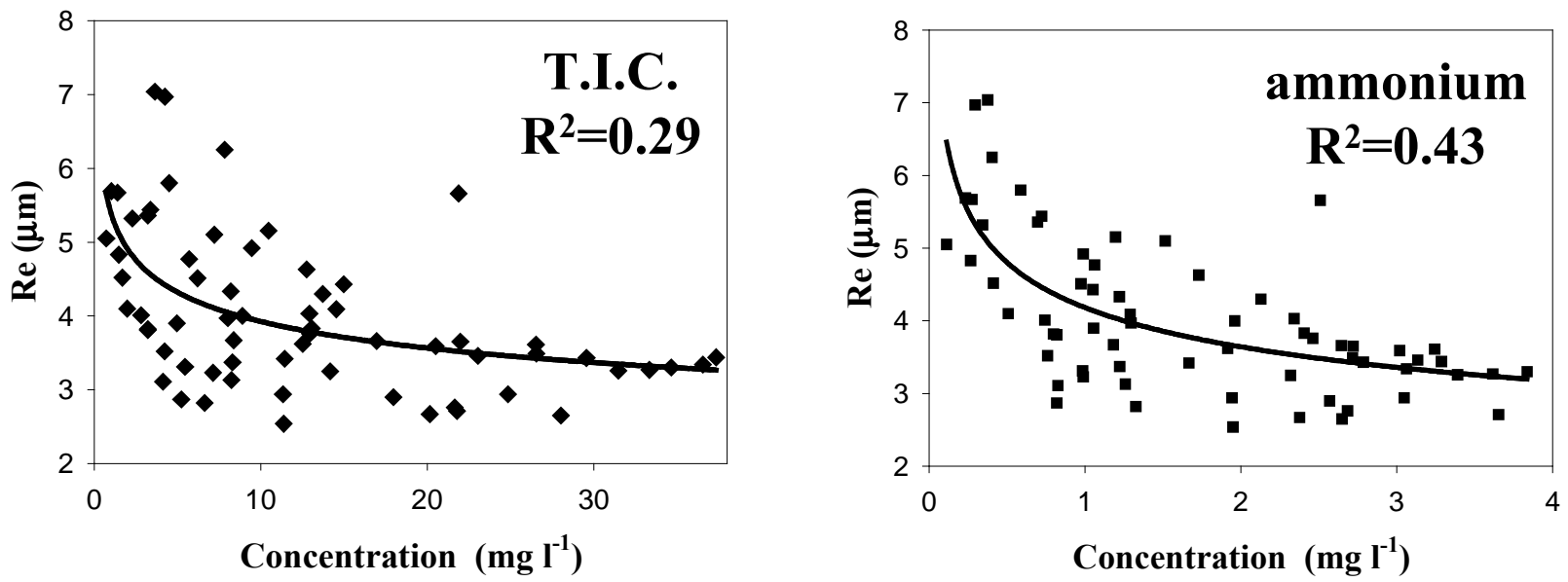

Fig. 6. Correlation between effective radius of droplets $(\mathrm{Re})$ and concentrations of all ions and ammonium.

cloud event or between events. Overall LWC values range from 0.06 to $0.58 \mathrm{~g} \mathrm{~m}^{-3}$, with $50 \%$ of the values being in the range 0.19 to $0.32 \mathrm{~g} \mathrm{~m}^{-3}$. This variability is much less important than that measured by previous authors, who reported inverse correlation (still weak, $\mathrm{R}^{2}=0.52$ in Möller et al., 1996) that were driven mostly by events with very low and very high LWC.

The very high contribution of gas-phase species in PDD clouds limits the correlation between cloud water solute concentration and LWC that is expected from nucleation scavenging. To some degree, a weak relationship exists between total aerosol number measured by CPC $\left(\mathrm{N}_{\mathrm{CPC}}\right)$ and TIC (in $\mu$ eq $\left.1^{-1}\right)\left(\mathrm{R}^{2}=0.30\right)$ or CWL $\left(\mathrm{R}^{2}=0.52\right)$. The chemical species that drives this correlation is sulphate, displaying the highest coefficient of correlation $\left(\mathrm{R}^{2}=0.69\right)$. Higher $\mathrm{N}_{\mathrm{CPC}}$ leads to more, but smaller droplets, with the droplet radius being inversely proportional to the $\mathrm{N}_{\mathrm{CPC}}\left(\mathrm{R}^{2}=0.68\right)$.

The $\mathrm{N}_{\mathrm{CPC}}$ correlations are somewhat concordant with the findings of Elbert et al. (2000), who proposed the use of CWL, rather than TIC, as a diagnostic parameter for (i) the characterization of the local and regional degree of an- thropogenic pollution, and (ii) the large-scale comparison of chemical components in cloudy environments. However, the weakness of the correlations within the measured range of LWC values results in a very high uncertainty associated with estimations of CWL (or TIC) that are only derived from aerosol parameters.

Instead, the liquid concentration is a power function of droplet radius ( $\mathrm{Re}$ ), with a correlation of $\mathrm{R}^{2}=0.29$; among the solutes, $\mathrm{NH}_{4}^{+}$has the highest correlation with $\mathrm{Re}\left(\mathrm{R}^{2}=0.43\right)$, followed by $\mathrm{NO}_{3}^{-}\left(\mathrm{R}^{2}=0.33\right)$ (see Fig. 6). It is interesting to note that atmospheric concentrations are driven particularly by aerosol particle concentration, while liquid concentrations are affected by the droplet dimension due to the stronger efficiency of gas transfer with the higher surface-to-volume ratio. In fact, $\mathrm{NH}_{4}^{+}$in cloud water originates predominantly from the gas phase, while the contribution of $\mathrm{SO}_{4}^{2-}$ is highest from aerosol particles (Sellegri et al., 2003c). 


\section{Conclusions}

We have derived a representative data set for chemical composition of clouds at PDD in winter/spring. Three different kinds of clouds were recognized and classified in the free continental troposphere: background continental (BG), anthropogenic influenced (ANT), and special events (SpE). This classification is consistent with the aerosol classification proposed by Sellegri et al. (2003a), whilst acknowledging that the Saharan events detailed in the aforementioned study were not sampled during our sampling period.

- BG samples are characterized by low solute content $\left(<18 \mathrm{mg} \mathrm{l}^{-1}\right)$; these concentrations are similar to those of European high altitude sites that are far from local sources of pollution. The contribution of nitrate and sulphate to the TIC (44\%) is relatively limited, and does not confer a strong acidic character to cloud water. The contribution of Dissolved Organic Carbon to the solute concentration is surprisingly high $(28 \%)$, due mostly to the presence of mono-carboxylic acids (9\%). This kind of cloud is the most common during the wintertime.

- ANT samples have solute content values ranging from $18 \mathrm{mg}^{-1}$ to $50 \mathrm{mg}^{-1}$; these concentrations are slightly lower than ionic concentrations measured at mountain sites under the influence of medium range pollution, such as Great Dun Fell, Aubure in the Vosges Mountains, Whiteface Mountain, and in the eastern part of the United States. These samples are more acidic than BG samples, due mainly to the higher levels of nitrate $(36 \%)$. The presence of high levels of nitrate is also observed in the aerosol phase (Sellegri at al., 2003a). The contribution of DOC (21\%) to solute concentration decreases from BG to ANT due to a decrease in the contribution of both DOC and carboxylic acids. The longrange transport of atmospheric pollutants, mostly from northern Europe, has a substantial impact on the chemistry of continental clouds.

- SpE samples are infrequent, but they are found consistently at PDD. They are characterized by very high concentrations, and exhibit TIC values up to $160 \mathrm{mgl}^{-1}$. These very high concentrations are similar to those found in the much polluted regions of the Po Valley and the Czech Krusne Hory plateau, and are unexpected for samplings from a non-industrialized area. They are characterized not only by very high contributions of nitrate and sulphate (63\% overall), but also of ammonium (19\%), which keeps the pH close to ANT levels (4.55.5). The contribution of DOC in SpE samples is limited to $13 \%$ of the solute concentration. These findings may be attributed to the long-range transport of polluted air masses coupled with strong vertical mixing from the boundary layer, where $\mathrm{NH}_{3}$ emissions take place in the area of PDD.
Our results confirm the limited ability of organic compounds other than carboxylic acids to act as CCN. In addition, all cloud events are characterized by very high contributions from the gas phase to the liquid phase in cloud. This is evidenced by the larger contributions of nitrate, ammonium and mono-carboxylic acids to the solute content of cloud water relative to their contribution to the aerosol phase. The strong contribution of gases limits the establishment of the correlation between cloud water solute concentration and cloud microphysics (in particular LWC) that is expected from pure nucleation scavenging. This is contrary to the conclusions of Möller et al. (1996), Elbert et al. (2000) and Kasper-Giebl et al. (2000), though these authors did consider a larger range of LWC values. Regardless, the correlations of TIC and CWL with $\mathrm{N}_{\mathrm{CPC}}$ in the present study confirm that CWL can be used (i) as a diagnostic parameter for the characterization of the local and regional degree of anthropogenic pollution, and (ii) for large-scale comparison of chemical components in cloudy environments. Such a proposal is supported by the research of Elbert et al. (2000).

Acknowledgements. This work was supported by CNRS-INSU under the National Program for Atmospheric Research (PNCA) and by the Ministère de la Recherche under ACI-Jeune Chercheur to PL and ACI-ORE-BEAM project. Authors acknowledge additional financial support from the scientific council of region Auvergne and from Observatoire de Physique du globe de Clermont-Ferrand (OPGC). A. Marinoni acknowledges the financial support of Consiglio Nazionale delle Ricerche.

The authors gratefully acknowledge the NOAA Air Resources Laboratory (ARL) for the provision of the HYSPLIT transport and dispersion model and/or READY website (http://www.arl.noaa.gov/ready.html) used in this publication.

Edited by: N. Mihalopoulos

\section{References}

Aneja, V. P., Claiborn, C. S., Bradow, R. L., Paur, R. J., and Baumgardner, R. E.: Dynamic chemical characterisation of montain clouds, Atmos. Environ., 24A, 563-572, 1990.

Aneja, V. P.: Organic Compounds in Cloud Water and their Deposition at a Remote Continental Site, Air \& Waste, 43, 1239-1244, 1993.

Baltensperger, U., Schwikowski, M., Jost, D. T., Nyeki, S., Gäggeler, H. W., and Poulida, O.: Scavenging of atmospheric constituents in mixed phase clouds at the high-alpine site Jungfraujoch, Part I: Basic concept and aerosol scavenging by clouds, Atmos. Environ., 32, 3975-3983, 1998.

Brantner, B., Fierlinger, H., and Puxbaum, H.: Cloud water chemistry in the subcooled droplet regime at Mount Sonnblich (3106 m a.s.l., Salzburg, Austria), Water, Air and Soil Pollution, 74, 363-384, 1994.

Bridges, K. S., Jickells, T. D., Davies, T. D., Zeman, Z., and Hunova, I.: Aerosol, precipitation and cloud water chemistry observations on the Czech Krusne Hory plateau adjacent to a heavily industrialised valley, Atmos. Environ., 36, 353-360, 2002. 
Calvert, J. G., Lazrus, A. L., Kok, G. L., Heikes, B. G., Walega, J. G., Lind, J., and Cantrell, C. A.: Chemical mechanisms of acid generation in troposphere, Nature, 317, (6032), 27-35, 1986.

Cappiello, A., De Simoni, E., Fiorucci, C., Mangani, F., Palma, P., Trufelli, H., Decesari, S., Facchini, M. C., and Fuzzi, S.: Molecular Characterization of the Water-Soluble Organic Compounds in Fogwater by ESIMS/MS, Environ. Sci. Technol., 37, (7), 12291240, 2003.

Chameides, W. L. and Davis D. D.: Aqueous phase source of formic acid in clouds, Nature, 304, 427-429, 1983.

Chandler, A. S., Choularton, T. W., Dollard, G. J., Gay, M. J., Hill, T. A., Jones, A., Jones B. M. R., Morse, A. P., Penkett, S. A., and Tyler, B. J.: A field study of the cloud chemistry and cloud microphysics at Great Dun Fell, Atmos. Environ., 22, 683-694, 1988a.

Chandler A. S., Choularton, T. W., Dollard G. J., Eggleton, A. E. J., Gay, M. J., Hill, T. A., Jones, B. M. R., Tyler, B. A., Bandy, B. J., and Penkett, S. A.: Measurements of $\mathrm{H}_{2} \mathrm{O}_{2}$ and $\mathrm{SO}_{2}$ in cloud and estimates of their reaction rate, Nature 336, 562-565, 1988b.

Chebbi, A. and Carlier P.: Carboxylic acids in troposphere, occurrence, sources and sinks: a review, Atmos. Environ., 23, 9991007, 1996.

Collett, J., Oberheolzer, B., and Staehlin, J.: Cloud chemistry at Mt. Rigi, Switzerland: dependence on drop size and relationship to precipitation chemistry, Atmos. Environ., 27A, 33-42, 1993.

Collett, J., Iovinelli, R., and Demoz, B.: A three-stage cloud impactor for size resolved measurement of cloud drop chemistry, Atmos. Environ., 29, (10), 1145-1154, 1995.

Collett, J. L., Hoag, K. J., Rao, X., and Pandis, S. N.: Internal acid buffering in San Joaquin Valley fog drops and its influence on aerosol processing, Atmos. Environ., 33, (29), 4833-4847, 1999.

Decesari, S., Facchini M. C, Matta, E., Lettini, F., Mirccea, M., Fuzzi, S., Tagliavini, E., and Putaud, J.-P.: Chemical features and seasonal variation of fine aerosol water-soluble organic compounds in the Po Valley, Italy, Atmos. Environ., 35, 3691-3699, 2001.

Dupuy, R., Sellegri, K., and Laj, P.: Empirical relationship between aerosol number and cloud microphysical properties, in Atmospheric Chemistry within the Earth System: from regional pollution to global change, 7th Conference of the IGAC Heraklion, Crete, 18-25 September 2002.

Elbert, W., Hoffmann, M. R., Krämer, M., Schmitt, G., and Andreae, M. O.: Control of solute concentrations in cloud and fog water by liquid water content, Atmos. Environ., 34, 1109-1122, 2000.

Erel, Y., Pehkonen, S. O., and Hoffmann M. R.: Redox chemistry of iron in fog and stratus clouds, J. Geophys. Res., 98, (D10), $18423-18434,1993$.

Flossmann, A. I.: Cloud Ice Mountain Experiment (CIME), Final report of CEE, contract ENV4-CT95-0012, Aubière, France Laboratoire de Météorologie Physique, 112, 2000.

Führer, J.: Chemistry of fogwater and estimated rates of occult deposition in an agricultural area of Central Switzerland, Agric. Ecosyst. Environ., 1986.

Fuzzi, S.: Radiation fogchemistry and microphysics, in Chemistry of Multiphase Atmospheric Systems, edited by Jaeschke, W., Springer, Berlin, 213-226, 1986.

Fuzzi, S., Orsi, G., Nardini, G., Facchini, M. C., McLaren, S., McLaren, E., and Mariotti, M.: Heterogeneus processes in the Po
Valley radiation fog, J. Geophys. Res., 93, (D9), 11 141-11 151, 1988.

Fuzzi, S., Facchini, M. C., Orsi, G., Lind, J. A., Wobrok, W., Kessel, M., Maser, R., Jaeschke, W., Enderle, K. H., Arends, B. G., Berner, A., Solly, I., Kruisz, C., Reischl, G., Pahl, S., Kaminski, U., Winkler, P., Ogren, J. A., Noone, K., Hallberg, A., Grieser, J., Fierlinger-Oberlinninger, H., Puxbaum, H., Marzorati, A., Hansson, H. C., Wiedensohler, A., Svenningsson, I. B., Martinsson, B. G., Schell, D., and Georgii, H. W.: The Po Valley Fog Experiment 1989, an overview, Tellus, 44B, 545-555, 1992.

Fuzzi, S. and Zappoli, S.: The organic component of fog droplets, in 12th International Conference on Clouds and Precipitation, 1996.

Fuzzi, S., Laj, P., Facchini, M. C., Ricci, L., and Berner, A.: Sizedependant chemistry of fog and cloud droplets, in First International conference on fog and fog collection, Vancouver, Canada, edited by Schemenauer, R. S. and Bridgam, H., 1998.

Gervat, G. P, Kallend, A. S., and Marsh, A. R. W.: Composition and origin of cloudwater solutes, in: Physico-Chemical behaviour of Atmospheric Pollutants, edited by Versino, B. and Angeletti, G., Reidel, Dordrecht, 506-516, 1984.

Glotfelty, D. E., Seiber, J. N., and Liljedahl, L. A.: Pesticides in fog, Nature, 325, 602-605, 1987.

Hadi, D. A., Crossley, A., and Cape, J. N.: Particulate and Dissolved Organic Carbon in cloud water in Southern Scotland, Environ. Pollut., 88, 299-306, 1995.

Hegg, D. A. and Hobbs, P. V.: Sulphate and nitrate chemistry in cumuliform clouds, Atmos. Environ., 20, 901-909, 1986.

Herckes, P., Mirabel, P., and Wortham, H.: Cloud water deposition at high-elevation site in the Vosges Mountains (France), Sci. Total Environ., 296, 59-75, 2002.

Herckes, P., Hannigan, M. P., Trenary, L., Lee, T., and Collett Jr., J. L.: The organic composition of radiation fogs in Davis (California), Atmos. Res., 64, 99-108, 2002.

Hitzenberger, R., Berner, A., Kromp, R., Kasper-Giebl, A., Limbeck, A., Tscherwenka, W., and Puxbaum, H.: Black carbon and other species at a high-elevation European site (Mount Sonnblick, $3106 \mathrm{~m}$, Austria): Concentrations and scavenging efficiencies, J. Geophys. Res., 105, (D20), 24 637-24 645, 2000.

Jacob, D. J.: Fogwater collector design and characterization, Environ. Sci. Technol., 18, 827-833, 1984.

Jacob, D. J., Munger J. W., Waldman J. M., and Hoffmann M. R.: The $\mathrm{H}_{2} \mathrm{SO}_{4}, \mathrm{HNO}_{3}, \mathrm{NH}_{3}$ system at high humidities and in fogs: I. Spatial and temporal patterns in San Joaquin Valley of California, J. Geophys. Res., 91, 1073-1088, 1986.

Jacob, D. J., Shair, F. H., Waldman, J. M., Munger, J. W., and Hoffmann M. R.: Transport and oxidation of $\mathrm{SO}_{2}$ in a stagnant foggy valley, Atmos. Environ., 21, 1305-1315, 1987.

Jaeschke, W.: Chemistry of Multiphase Atmospheric Systems, Springer, Berlin, 1986.

Jaffrezo, J.-L., Calas, N., and Bouchet, M.: Carboxylic acid measurements with ionic chromatography, Atmos. Environ., 32, 2705-2708, 1998.

Junge, C. E.: Air Chemistry and Radioactivity, Academic Press, New York/London, 1963.

Kasper-Giebl, A., Koch, A., Heitzemberg, R., and Puxbaum, H.: Scavenging efficiency of "aerosol carbon" and sulphate in super cooled clouds at Mount Sonnblick (3106 m a.s.l., Austria), J. Atmos. Chem., 35, 33-46, 2000.

Khwaja, H. A., Brudnoy, S., and Husain, L.: Chemical characteri- 
sation of three summer cloud episodes ay Witheface Mountain, Chemosphere, 31, (5), 3357-3381, 1995.

Krivacsy, Z., Kiss, G., Varga, B., Galambos, I., Sarvari, Z., Gelencser, A., Molnar, A., Fuzzi, S., Facchini, M. C., Zappoli, S., Andracchio, A., Alsberg, T., Hansson, H.-C., and Persson, L.: Study of humic-like substances in fog and interstitial aerosol by size-exclusion chromatography and capillary electrophoresis, Atmos. Environ., 34, 4273-4281, 2000.

Kruisz, C., Berner A., and Brantner, B.: A cloud water sampler for high wind speeds, Proceedings of the EUROTRAC Symposium 1992, edited by Borrell, P. M., SPB Acad., The hague Netherlands, 523-525, 1993.

Laj, P., Fuzzi, S., Facchini, M. C., Orsi, G., Berner, A., Kruisz, C., Wobrock, W., Beswick, K. M., Gallagher, M. W., Colvile, R. N., Choularton, T. W., Nason, P., and Jones, B.: Experimental evidences for in-cloud production of aerosol sulphate, Atmos. Environ., 31, (16), 2503-2514, 1997a.

Laj, P., Fuzzi, S., Facchini, M. C., Lind, J. A., Orsi, G., Preiss, M., Maser, R., Jaeschke, W., Seyffer, E., Arends, B. G., Mölls, J. J., Acker, K., Wieprecht, W., Möller, D., Colville, R. N., Gallagher, M. W. Beswick, K. M., Hargreaves, K. J., Storeton-West, R. L., and Sutton, M. A.: Cloud processing of soluble gas, Atmos. Environ., 31, 2589-2592, 1997b.

Laj, P., Flossman, A. I., Wobrock, W., Fuzzi, S., Orsi, G., Ricci, L., Mertes, S., Swarzenbock, A., Heitzenberg, J., and Ten Brink, H.: Behaviour of $\mathrm{H}_{2} \mathrm{O}_{2}, \mathrm{NH}_{3}$, and black carbon in mixed-phase clouds during CIME, Atmos. Res., 58, 315-336, 2001.

Lanquette, A.-M., Pichon, J.-M., and Pointin, Y.: Physicalchemistry data of the Puy de Dôme top station, http://www.obs. univ-bpclermont.fr/observ/chimie/pdd_listedata.html, 2002.

Lawrence, M. G. and Crutzen, P. J.: The impact of cloud particle gravitational settling on soluble trace gas distribution, Tellus, 50B, (3), 263-289, 1998.

Lelieveld, J. and Crutzen, P. J.: The role of clouds in tropospheric photochemistry, J. Atmos. Chem., 12, 229-267, 1991.

Liang, J. and Jacobson, M. Z.: A study of sulphur oxidation pathways over a range of liquid water contents, $\mathrm{pH}$ values and temperature, J. Geophys. Res., 104, 13 749-13 769, 1999.

Limbeck, A. and Puxbaum, H.: Dependence of in-cloud scavenging of polar organic aerosol compounds on the water solubility, J. Geophys. Res., 105, 19857-19867, 2000.

Löflund, M., Kasper-Giebl, A., Schuster, B., Giebl, H., Heitzemberg, R., and Puxbaum, H.: Formic, Acetic, Oxalic, Malonic and Succinic Acid Concentrations and their Contribution to Organic Carbon in Cloud Water, Atmos. Environ., 36, (9), 1553-1558, 2002.

Mertes, S., Schwarzenböck, A., Laj, P., Wobrock, W., Pichon, J. M., Orsi, G., and Heintzenberg, J.: Changes of cloud microphysical properties during the transition from supercooled to mixed-phase conditions during CIME, Atmos. Res., 58, (4), 267-294, 2001.

Möller, D., Acker, K., and Wieprecht, W.: A relationship between liquid water content and chemical composition in clouds, Atmos. Res., 41, 321-335, 1996.

Munger, J. W., Jacob, D. J., Waldman, J. M., and Hoffmann, M. R.: Fogwater chemistry in a urban atmosphere, J. Geophys. Res., 88, 5109-5121, 1983.
Novakov, T. and Penner, J. E.: Large Contribution of Organic Aerosols to Cloud-Condensation-Nuclei Concentrations, Nature, 365, 823-826, 1993.

Pilié, R. J., Mack, E. J., Koemond, W. C, Eadie, W. J., and Rogers, C. W.: The life cycles of valley fog, Part II: Fog microphysics, J. Appl. Meteorol., 14, 364-374, 1975.

Poulida, O., Schwikowski, M., Baltensperger, U., Staehelin, J., and Gaeggeler, H. W.: Scavenging of atmospheric constituents in mixed phase clouds at the high alpine site Jungfraujoch-Part II: influence of riming on the scavenging of particulate and gaseous chemical species, Atmos. Environ., 32, (23), 3985-4000, 1998.

Pruppacher, H. R. and Jaenicke, R.: The processing of water vapour and aerosols by atmospheric clouds, a global estimate, Atmos. Res., 38, 283-295, 1995.

Schaap, M., Müller, K., and Ten Brink, H. M.: Constructing the European aerosol nitrate concentration field from quality analysed data, Atmos. Environ., 36, (8), 1323-1335, 2002.

Sellegri, K., Laj, P., Peron, F., Dupuy, R., Legrand, M., Preunkert, S., Putaud, J.-P., Cachier, H., and Ghermandi, G.: Mass balance of free tropospheric aerosol at the Puy de Dôme (France) in winter, J. Geophys. Res., 108, (D11), 4333, 2003a.

Sellegri, K., Laj, P., Dupuy, R., Legrand, M., Preunkert, S., and Putaud, J.-P.: Size-dependent scavenging efficiencies of multicomponent atmospheric aerosols in clouds, J. Geophys. Res., 108, (D11), 4334, 2003b.

Sellegri, K., Laj, P., Marinoni, A., Dupuy, R., Legrand, M., and Preunkert, S.: Contribution of gaseous and particulate species to droplet solute composition and concentration, Atmos. Chem. Phys., 3, 479-519, 2003c.

Voisin, D., Legrand, M., and Chaumerliac, N.: Scavenging of acidic gases $\left(\mathrm{HCOOH}, \mathrm{CH}_{3} \mathrm{COOH}, \mathrm{HNO}_{3}, \mathrm{HCl}\right.$, and $\left.\mathrm{SO}_{2}\right)$ and ammonia in mixed liquid-solid water clouds at the Puy de Dôme mountain, J. Geophys. Res., 105, (D5), 6817-6836, 2000

Warneck, P.: The equilibrium distribution if atmospheric gases between the two phases of liquid water clouds, in Chemistry of the Multiphasic Atmospheric Systems, NATO ASI Series, Vol. G6, edited by Jaeschke, W., Springer, Berlin, 1986.

Weathers, K. C., Likens, G. E., Bormann, F. H., Bicknell, S. H., Bormann, B. T., Daube, B. C., Eaton, J. S., Galloway, J. N., Keene, W. C., Kimball, K. D., McDowell, W. H., Siccama, T. G., Smiley, D., and Tarrant, R. A.: Cloudwater Chemistry from Ten Sites in North America, Environ. Sci. Technol., 22, 1018-1026, 1988.

Wobrock, W., Schell, D., Maser, R., Jaeschke, W., Georgii, H.-W., Wieprecht, W., Arends, B. G., Möls, J. J., Kos, G. P. A., Fuzzi, S., Facchini, M. C., Orsi, G., Berner, A., Solly, I., Kruisz, C., Svenningsson, I. B., Wiedensohler, A., Hansson, H.-C., Ogren, J. A., Noone, K. J., Hallberg, A., Pahl, S., Schneider, T., Winkler, P., Winiwarter, W., Colvile, R. N., Choularton, T. W., Flossmann, A. I., and Borrmann, S.: The Kleiner Feldberg Cloud Experiment 1990, An overview, J. Atmos. Chem., 19, 3-35, 1994 